\title{
The Discourse Function of Left Dislocation in Czech*
}

\author{
ANNE STURGEON \\ University of California, Santa Cruz
}

\section{Introduction}

Czech has two syntactically distinct left dislocation constructions which have not yet been discussed in the literature: Contrastive Left Dislocation (CLD) and Hanging Topic Left Dislocation (see also van Riemsdijk and Zwarts 1997, Vat 1997, Grohmann 2003). These two constructions differ both in their syntax and their function in the discourse. CLD constructions are derived through movement and are interpreted as contrastive topics (see also Prince 1981, Büring 2003). Hanging topics, on the other hand, are base generated in their surface position and the construction serves as a topic promoting device (Gundel 1988, Gregory and Michaelis 2001).

The preposing constructions discussed here are part of a larger typology in which movement preposings are paired with a contrastive topic interpretation, while non-movement constructions function to establish topics. In the conclusion I consider similar patterns in English, Bulgarian and German.

\section{Overview of Left Dislocation in Czech}

In both left dislocation constructions there is a constituent at the left edge separated from the following clause by an intonational break. A coreferent resumptive pronoun (usually a demonstrative) occurs obligatorily at the left edge of a clause which has all its argument positions filled. A clause internal gap is bound by the left dislocated element and the resumptive pronoun.

(1) $\quad$ Petr, $\underline{\text { ten }}$ si koupil chleba v krámu. ${ }^{1}$

Petr.nom that.nom refl-cl bought bread in store

'Petr, he bought bread at the store.'

\footnotetext{
* I thank Judith Aissen, Daniel Büring, Hana Filip, Eva Hajičová, James McCloskey, Line Mikkelsen, Petr Sgall and Lynsey Wolter for helpful comments on this project. I am indebted to my primary Czech consultants, Martina Šímová and Kristina Valendinová, for their tireless help. All remaining errors are my own.

${ }^{1}$ Abbreviations: nom 'nominative', acc 'accusative', dat 'dative', refl-cl 'reflexive clitic', neg

'negation', $s g$ 'singular', $p l$ 'plural', $C$ (complementizer)
} 
In (1), the left dislocated DP, Petr, is resumed by a demonstrative pronoun at the left edge of the main clause. These two elements corefer and the demonstrative is an argument (in this case the agent) of the verb.

CLD and hanging topic constructions also differ in several important ways. One difference is that, in CLD constructions, the left dislocated element matches the case of the resumptive pronoun. In (2), both the resumptive pronoun and the left dislocated element are in the accusative.

(2) Honzu, toho ještě neznám.

CLD

Honza.acc that.acc still neg-know.1sg

Honza, I still don't know him.

In hanging topic constructions, however, case matching is absent, (3). Left dislocated elements appear in the default case, nominative.

Anička? Té se nic nestalo. Hanging Topic Anička.nom that.dat refl-cl nothing neg-happened

'Anička? Nothing happened to her.' $\quad$ (Czech National Corpus) ${ }^{2}$

The hanging topic in (3), Anička, is nominative, but the resumptive is dative.

To account for case matching effects in CLD, I propose that these constructions are generated through movement of the left dislocated element from a clause-internal position to a specifier position dominating the clausal domain, [Spec, TopP]. A CP projection can intervene between TopP and IP; left dislocation co-occurs with wh-movement.

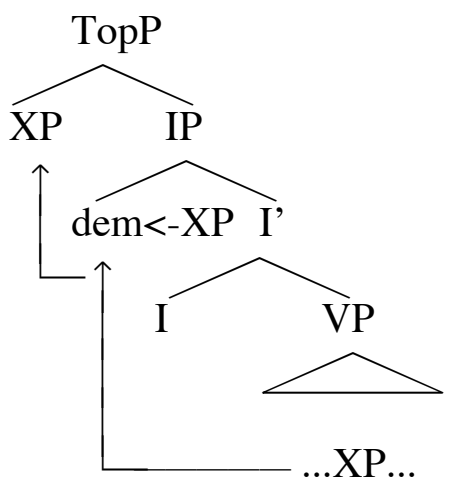

The left dislocated element moves from its base position within the clause, through [Spec, IP] to [Spec, TopP]. The resumptive pronoun is a Spelled-Out copy of the left dislocated element. Note that any XP can left dislocate in a CLD construction.

\footnotetext{
${ }^{2}$ The Czech National Corpus can be found on the web at www.ucnk.ff.cuni.cz.
} 
Hanging topic constructions have a different derivation. Since case matching and other reconstruction effects are absent, I suggest that hanging topics are base generated in a left edge position and related to the resumptive through coreference.

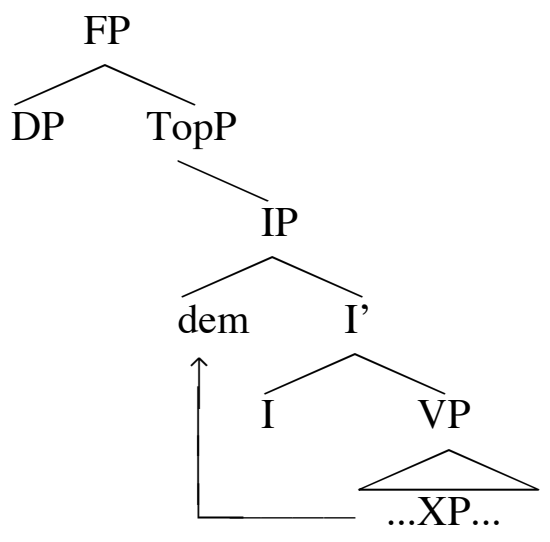

The hanging topic is generated in a specifier position of a functional projection which dominates TopP. The clause-internal demonstrative resumptive is topicalized (moves to [Spec, IP]). Hanging topics are limited to nominals.

\subsection{Evidence for a Movement Account of CLD}

There is a tight syntactic connection between the CLD'ed element and the clauseinternal gap. In addition to case matching between the CLD'ed element and the resumptive pronoun, there is evidence that left dislocated XP's reconstruct to a clause-internal position. In this section reconstruction effects from Condition A and quantifier binding are illustrated. The same results hold for Condition $\mathrm{C}$ (see also Sturgeon 2005).

Reflexive pronouns and possessives obey Condition A; they must be ccommanded by their antecedents at some point in the derivation (see also Sturgeon 2003). This suggests that these elements undergo reconstruction to a clauseinternal position. In (6) a possessive reflexive is CLD'ed. Note that accusative case matching holds between the CLD'ed element and the resumptive.

$\underline{S_{v e ́ h o}} \underline{1}_{1}$ nejlepšího prítele, toho má Honza ${ }_{1}$ rád.

CLD self's best friend.acc that.acc has Honza joy 'His ${ }_{1}$ best friend, Honza ${ }_{1}$ likes him.'

If reconstruction did not occur in (6), the reflexive possessive would not be ccommanded by its antecedent at any level of the derivation and would be expected to be ungrammatical.

The same pattern is found with bound elements. Quantificational DP's in Czech must c-command their bound pronominal. Bound pronominals occur in 
Anne Sturgeon

CLD constructions, (7). Note the case matching between the left dislocated element and the resumptive element.

(7) $\underline{\text { Svého }}_{1}$ nejlepšího přítele, toho má každý ${ }_{1}$ rád.

CLD self's best friend.acc, that.acc has every joy

'One's ${ }_{1}$ own best friend, everyone ${ }_{1}$ loves them.'

The grammaticality of (7) suggests that the bound pronominal was c-commanded by its antecedent at some level of the derivation. Reconstruction of the left dislocated element to a clause-internal position accounts for the grammaticality of this example.

Typical reconstruction effects are found in these constructions. The evidence in (6) and (7) can be explained if we assume that CLD'ed elements originate in a clause-internal position and move to the left edge.

\subsection{Evidence for a Non-movement Analysis of Hanging Topics}

There is no evidence that hanging topics originate in a clause-internal position. Hanging topic constructions do not exhibit reconstruction effects. It is not possible for reflexive or bound pronouns to be hanging topics and R-expressions can ccommand pronouns within the clausal domain (no Condition $\mathrm{C}$ reconstruction effects).

Reflexive possessives cannot appear in the hanging topic position; (8) is ungrammatical. I argue that this is because the reflexive is not c-commanded by its antecedent at any point in the derivation. Note the lack of case-matching between the hanging topic (nominative) and the resumptive element (accusative).

* Svoje $_{1}$ sestřenice Anička, $\underline{\text { uu }}$ má Honza 1 rád.

HTLD self's cousin Anna.nom that.acc have Honza joy 'His ${ }_{1}$ cousin Anna, Honza 1 likes her.'

The ungrammaticality of (8) is expected if hanging topics are not derived by movement, but are base generated at the left edge.

The same results are found with quantifier binding; a bound pronoun cannot occur as a hanging topic, (9). A lack of case matching suggests that this is a hanging topic and not a CLD construction.

* $\underline{S v u ̊ j}_{1}$ nejlepší prítel, $\quad \underline{\text { toho }}$ má každý ${ }_{1}$ rád.

HTLD self's best friend.nom, that.acc has every joy

'One's $\underline{s}_{1}$ own best friend, everyone ${ }_{1}$ loves them.'

Reconstruction to a clause-internal position of the hanging topic is not possible. The bound pronominal is not c-commanded by its antecedent at any point in the derivation and is, thus, ungrammatical. 


\section{The Discourse Function of Left Dislocation in Czech}

The data presented in this section suggest that a tight syntactic connection exists between the left dislocated element and the clause internal gap in CLD constructions. This is not true of HTLD constructions. In those constructions there is no evidence of reconstruction of the hanging topic to a clause-internal position, and, thus, no connection between hanging topics and the clause-internal gap. I suggest that these differences between the two constructions stem from their distinct syntactic derivations. CLD constructions involve movement of the left dislocated element from a clause-internal position to the left edge; while hanging topics are base generated in the left periphery of their clause.

\section{The Discourse Function of CLD}

In addition to being distinct syntactically, CLD and hanging topic constructions have different discourse functions. CLD'ed constituents are interpreted as contrastive topics while hanging topic constructions promote discourse entities to topic status. I turn first to CLD constructions.

\subsection{Contrastive Topic}

Prince 1981, 1998 and Büring 2003 discuss constructions which have an interpretation Büring calls 'contrastive topic' (see also Roberts 1996, Hajičová, et al 2003, among others). Büring argues that the B-accent (fall-rise) marks contrastive topics in English (Jackendoff 1972). The B-accent contrasts with the A-accent (rise) which is associated with a focus interpretation. In the following examples I mark contrastive topics as $\mathrm{CT}$ and foci as F.

(10) a. Where were you at the time of the murder?

b. $\mathrm{I}_{\mathrm{CT}}$ was at home . $_{\text {. }}$

(Roberts 1996: 122)

The contrastive topic intonation on $I$ in (10b) leads the hearer to expect that there will be answers to questions parallel to (10a) that involve alternatives to the contrastive topic: But Bill $C$ was at the bar $_{F}$. These alternatives need not appear overtly in the discourse, but they are implied by the use of this intonational pattern. More specifically, Büring asserts that the contrastive topic accent in (10b) indicates that a question such as (10a) is active in the discourse and conversationally implicates the existence in the discourse of questions about alternatives to the contrastive topic, for instance: Where was Bill at the time of the murder? ${ }^{3}$

Prince 1981, 1998 discusses another construction in English which serves to mark contrastive topics: topicalization. In (11) there are three alternative groups of mice under discussion.

\footnotetext{
${ }^{3}$ Under Büring 2003, the existence of (at least one) alternative question is part of the conventional meaning of contrastive topic marking. That this alternative question is about an alternative to the contrastive topic (rather than about the same entity) is a conversational implicature.
} 
(11) a. She had an idea for a project. She's going to use three groups of mice.

b. One ${ }_{\mathrm{CT}}$ she'll feed mouse $\operatorname{chow}_{\mathrm{F}} \cdots$

c. Another $\mathrm{C}_{\mathrm{C}}$ she'll feed veggies $\mathrm{F}_{\mathrm{F}}$.

d. And the third ${ }_{\mathrm{CT}}$ she'll feed junk food . $_{\mathrm{F}}$.

(Prince 1998: (14))

The topicalization construction in (11b) raises alternative questions which are answered overtly in the discourse: What will she feed another group of mice?, What will she feed the third group of mice? Another feature of contrastive topic constructions is that they must contain a focused element. In (11) focus falls on the accusative argument (types of food fed to mice) and, in (10), on the locative. Generally, the focus values associated with the alternatives differ. This is true in the example in (11); the speaker pairs each group of mice with a different food: one group of mice/mouse chow, another/veggies, the third/junk food.

Büring 2003 points out that sentences which contain contrastive topic marking are partial answers to a larger question under discussion. For instance, in (11) the topicalization constructions address the larger question, What will she feed which group of mice? Büring 2003 represents the discourse function of contrastive topic marking constructions in discourse trees. A tree for (11) is given in (12).

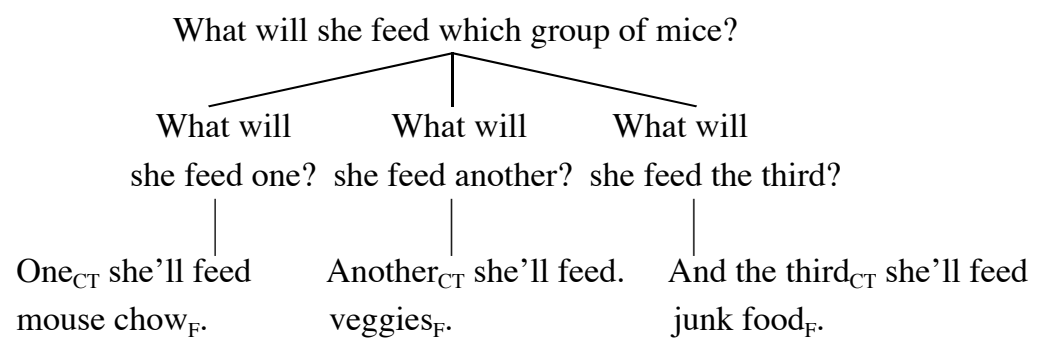

Topicalization in (11b) indicates that the question, What will she feed one (group of mice)?, is active in the discourse and conversationally implicates that the alternative questions (sisters to What will she feed one?) are also active. The three topicalization structures are partial answers to the larger question under discussion: What will she feed which group of mice?

\subsection{CLD and Contrastive Topicalization}

All textual and elicited examples of Czech CLD suggest that it is a contrastive topic marking construction. When eliciting examples of CLD, speakers generally insist on continuations that involve contrast between the discourse referent of the left dislocated element and another entity in the discourse. In the constructed example in (13), the speaker is comparing the bags bought by Hana and Jana. Case matching between the left dislocated element and the resumptive pronoun provides evidence that this is a CLD construction. 


\section{The Discourse Function of Left Dislocation in Czech}

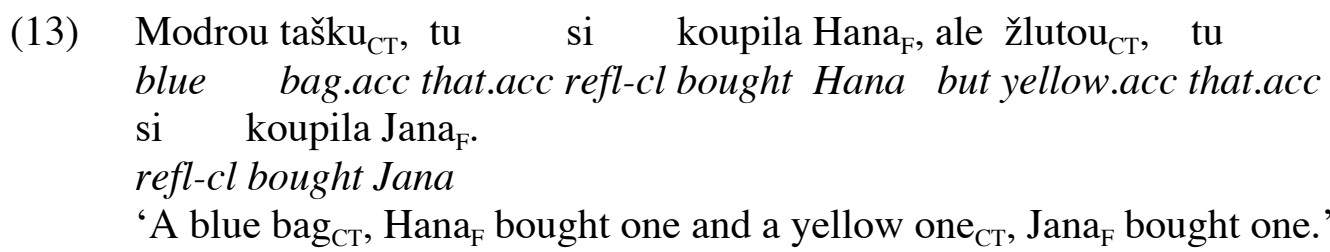

Speakers report that the conjuncts in (13) form a coherent discourse. The use of the CLD construction in the first conjunct suggests to the hearer that there are alternatives to modrou tašku 'blue bag' in the discourse, for instance, žlutou 'yellow one'. Moreover, contrastive topic marking indicates that the question, Who bought a blue bag?, is active in the discourse and conversationally implicates that alternative questions are also active, for instance, Who bought a yellow bag? Note that the focused subject arguments (Hana, Jana) occur at the right edge of the clause, a typical position for focused elements in Czech.

In the spontaneous corpus example in (14), the speaker is contrasting two discourse entities pictured in a photograph posted online: that guy (who he does not know) and Prochor (who he knows). The CLD'ed element and alternatives to it are underlined.

(14) a. Jinák kdo zná toho kluka, že aspoň zasmeje... alternatively who knows that guy $C$ at-least will-smile

b. Toho kluka??? Toho neznám, ale Prochora v něm poznávám. that guy.acc that.acc neg-know but Prochor in it recognize

'Anyway, whoever knows that guy will at least laugh...That guy? I don't know him, but Prochor I recognize from the picture. ${ }^{4}$ (http://www.dfklub.cz/gallery/opinion.php?id=10917)

Again, the use of CLD in the first conjunct suggests to the hearer that alternatives to the CLD'ed element (that guy) are under consideration. The speaker considers both alternatives (that guy and Prochor) with respect to the question: Do you know $X$ ? Answers to those questions are overtly provided for both alternatives. Again, the focus value, in this case clausal polarity, changes between the two alternatives. One is known to the speaker, the other is not.

A final textual example is considered in (15). The speaker is discussing immigration to Canada and is considering types of individuals and whether or not they would be allowed to immigrate. A family with children or a locksmith could

\footnotetext{
${ }^{4}$ As in the English translation, the alternative, Prochor, is contrastively topicalized in Czech; elements with this discourse function appear at the left edge of the clause and are associated with an optional intonational rise (Hajičová et al 2003. Contrastive topicalization also marks contrastive topics.
} 
Anne Sturgeon

immigrate, but an unmarried intellectual would not be allowed to. The final alternative, an unmarried intellectual occurs in a CLD construction.

(15) a. „Tak na Kanadu zapomeňte! Tam svobodnýho nevezmou...Akorat so on Canada forget there unmarried neg-take exactly možna tak rodinky s dětma."---,,Vždyt" tuhle vzali toho maybe so family with children to-be-sure over-there took that zámečníka..." „Jo, zámečníka snad. locksmith yeah, locksmith maybe.

b. Ale svobonýho INTELEKTUALA, toho tam nevezmou. A taky but unmarried intellectual that there neg-take and also

c. na Kanadu tak dobře přes rok čeká. Oni tam mají dobrej socijal...“ on Canada so well over year waits they there have good social

"Forget about going to Canada. They won't take an unmarried person there...OK, Maybe a family with children."---"To be sure, they took that locksmith..." "Yeah, a locksmith. But an unmarried intellectual, they wouldn't take one... And also for Canada you have to wait longer than a year. They have good social programs..."

(Czech National Corpus)

The use of the CLD construction in this example suggests that there are alternatives to the contrastive topic (an unmarried intellectual) in the discourse; alternatives include: a family with children, a locksmith. The speaker considers three types of individuals with respect to the question, Can they immigrate to Canada?

This example differs from the previous ones in that it is the final alternative which is marked as a contrastive topic, rather than all alternatives. Possibly, the discourse can be retroactively structured as containing alternative questions by the use of CLD in the final alternative. A full explanation of this pattern, however, is a question for future research.

The discourse function of CLD constructions is to mark contrastive topics. Results from elicitation as well as corpus studies support this conclusion. Hanging topics, however, have a different function in the discourse.

\section{Topic Promotion and Hanging Topics}

I analyze the discourse function of Czech hanging topic constructions as that of topic promotion, following the Gregory and Michaelis 2001 analysis of hanging topic constructions in English (see also Gundel 1988, Prince 1998).

When hanging topic constructions are used there is no evidence that any alternative questions are being raised. In (16) this is due to the fact that there are no other discourse referents under discussion. Lack of case matching in (16) indicates that this is a hanging topic and not a CLD construction. The hanging topic and subsequent mentions of the discourse referent it refers to are underlined. 
(16) a. „Jonatáne...vyleštîs nám hezky auto, zadarmo tě živit nebudem,“ Jonatán shine us well car for-free you support.inf neg-will.1pl a Šebestová šeptala za plotem Machovi, ,človeče, to je děsný, and Šebestová whispered behind fence Mach.dat man it is horrible oni si $\mathrm{z}$ něho udělali úplnýho otroka, they refl-clfrom him made totally slave

b. chudinka malej, toho čeká pěknej život.“... poor-thing small.nom that.acc waits nice life

c. "radši z něho uděláme třeba vrabce nebo sykorku, aspoň better from him make.1pl maybe sparrow or chickadee at-least bude volnej jako pták..." would-be free like bird

“"Jonatán...shine our car, we aren't going to support you for free." And Šebestová whispered behind the fence to Mach, "hey, it's horrible how they are making him a slave, poor thing, a nice life had been awaiting him."..."It would be better for us to make him a sparrow or a chickadee, at least then he would be as free as a bird..." (Czech National Corpus)

The discourse participants, Mach and Šebestová, are discussing one discourse entity, Jonatán, with respect to the proposition, a nice life had been awaiting him. There is no alternative to this discourse referent with another life situation (for instance: lucky dog, a nice is awaiting him).

In order to determine if the Czech hanging topic construction is topic promoting, it is necessary to consider the properties of topical entities. Gregory and Michaelis 2001 suggest that topics are connected to both the previous and the following contexts. They have been evoked in the previous discourse either by prior mention or by being a member of a previously mentioned set. Topics also tend to perseverate in the following context. Gregory and Michaelis follow Givón 1984 and define topic persistence as: 'the number of times the referent persists as an argument in the subsequent ten clauses following the current clause' (Givón 1984: 908). Gregory and Michaelis found that considering the following five clauses is adequate and I follow them in that conclusion. The discourse referents of Czech hanging topics are topical in the sense of Gregory and Michaelis.

Consider the example in (17). The discourse referent of the hanging topic ( $M r$. Kopyto) has been previously evoked in the discourse and additional information is provided about him in the clauses following the hanging topic construction.

(17) a. ...Paní Štěrnová zvolala: „Pan Kopyto!“ ... Otto seděl a mlčel. ... Mrs. Sternova called Mr. Kopyto Otto sat andwas-silent Pomyslil si, co je to za divné jméno a kdo to vůbec je. thought.3sg refl-cl what is it from strange name and who it at-all is 
b. „Pan Kopyto, toho oni neznají. Mr. Kopyto.nom that.acc you neg-know

c. To je jeden znamý od Backru,“ řekla babička. „Je to nejaký it is one acquaintance from Backra said grandma is it some badatel překládá $\mathrm{z}$ jazyka německého...Germanist a scholar translated from language German Germanist and sberatel... Nosí velký brejle a má hluboký hlas..." antiquarian wears large glasses and has deep voice

‘And all of a sudden Mrs. Sternova called, "Mr. Kopyto!"...Otto was sitting and stayed quiet. He was thinking, what a strange name and who is that. "Mr. Kopyto, you don't know him. He is an old acquaintance from Backra," said grandma. " He is some sort of scholar; he translates Ge r-

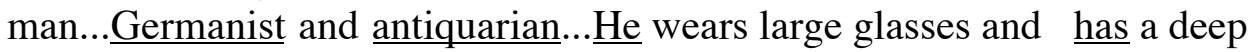
voice..."

(Czech National Corpus)

The discourse referent of the hanging topic, Mr. Kopyto, has both topic properties discussed in Gregory and Michaelis: it has been previously evoked and perseverates in the discourse. Mr. Kopyto is mentioned in argument positions in six of the following clauses. ${ }^{5}$ The same results hold in (17). The discourse referent of the hanging topic, Jonatán, has been mentioned in the previous context and persists in two of the following clauses.

The discourse referents of CLD'ed XP's are not topical in the sense of Gregory and Michaelis. Though the discourse referents of CLD'ed elements are members of previously mentioned sets (the set of people who could immigrate to Canada, (15); the set of elements in an online photo, (14)), these discourse referents do not perseverate in the discourse. In $67 \%$ of tokens of hanging topic constructions the discourse referent persists for two or more clauses, but this is true in only $13 \%$ of CLD constructions.

Consider the CLD example in (16). The speaker considers several types of individuals with respect to whether or not they could immigrate to Canada. After the CLD construction, the discourse turns to details about immigration in general. Additional information about unmarried intellectuals, for example, is not provided. The purpose of CLD is to consider several entities with respect to a question in the discourse, not to promote a discourse entity to topic status.

Hanging topic constructions, however, are topic promoting. A non-topical entity is promoted to topic status through this construction. Perseveration in the discourse is an important piece of evidence supporting this claim.

\footnotetext{
${ }^{5}$ An additional question for a 'topic promotion' analysis is whether the discourse referent of the hanging topic is already topical. While space limitations prevent a thorough discussion of this issue, analysis of corpus examples suggests that these discourse referents are non-topical (not the backward looking center of the previous clause) under a Centering Theory analysis of topicality (for Centering Theory see Grosz, et al 1995 and references therein).
} 


\section{Conclusion}

These two constructions (CLD and hanging topic) are part of a larger typology of preposing constructions. The evidence presented here suggests a connection between a contrastive topic interpretation and preposing constructions involving movement. The non-movement construction, hanging topic, does not have a contrastive topic interpretation, but, rather, promotes elements to topichood. This pattern is also found in other languages with more than one preposing construction: English, Bulgarian and German. The English preposing construction, topicalization, has a contrastive topic discourse function, while the non-movement construction, hanging topic, has a topic promotion function.

The same is true for Bulgarian and German. Arnaudova 2005 analyzes two Bulgarian preposing constructions: Clitic Left Dislocation (CLLD) and topicalization. She finds that the movement construction, topicalization, has a contrastive topic interpretation along the lines of Büring 2003, while the non-movement CLLD has a topic/comment structure. The same appears to be true of German. Although he works within a different framework, Frey's 2005 analysis left dislocation in German suggests that German CLD constructions (analyzed as involving movement by Grohmann 2003) have a 'contrastive flavor' along the lines of contrastive topic, while the non-movement hanging topic constructions do not. Hanging topic constructions serve, instead, to introduce new discourse referents. A question to consider is why this pairing between movement and contrastive topic might hold across languages.

\section{References}

Arnaudova, Olga. 2005. Two types of topics and what they can tell us about argument saturation. Presented at the Linguistics Society of America, Oak land, Ca. Meeting.

Büring, Daniel. 2003. On D-Trees, Beans and B-Accents. Linguistics \& Philosophy 26(5):511-545.

Frey, Werner. 2003. Notes on the syntax and pragmatics of German Left Dislocation. In H. Lohnstein and S. Trissller, eds., The Syntax and Semantics of the Left Periphery. 203-234. Berlin: Mouton de Gruyter.

Givón, Talmy. 1983. Topic continuity in discourse: An introduction. In T. Givón, ed., Topic Continuity in Discourse. 4-41. Amsterdam: John Benjamins.

Gregory, Michelle L and Laura A. Michaelis. 2001. Topicalization and leftdislocation: A functional opposition revisited. Journal of Pragmatics 33: 1665-1706.

Grohmann, Kleanthes. 2003. Prolific Domains: on the anti-locality of movement dependencies. Amsterdam: John Benjamins.

Grosz, Barbara J, Aravind Joshi, and Candace Sidner. 1995. Centering: a framework for modeling the local coherence of discourse. Computational Linguistics 21(2):203-25. 
Anne Sturgeon

Gundel, Jeannette. 1988. The Role of Topic and Comment in Linguistic Theory. New York: Garland Publishing.

Hajičová, Eva, Petr Sgall and Kateřina Veselá. 2003. Information structure and contrastive topic. In W. Browne, J.-Y. Kim, B. Partee and R. A. Rothstein, eds., Proceedings from the Annual Workshop on Formal Approaches to Slavic Linguistics. 219-234. Ann Arbor, MI: Michigan Slavic Publications.

Jackendoff, Ray. 1972. Semantics in Generative Grammar. Cambridge, Mass: MIT Press.

Prince, Ellen. 1981. Topicalization, Focus-Movement and Yiddish-Movement: A pragmatic differentiation. In D. K. Alford, K. A. Hunold, M. A. Macaufay, J. Walter, C. Brugman, P. Chertok, I. Civkulis and M. Toby, eds., Proceed ings of the $7^{\text {th }}$ Annual Meeting of the Berkeley Linguistics Society. 249-264. Berkeley, Ca.: Berkeley Linguistics Society.

Prince, Ellen. 1998. On the functions of Left-Dislocation in English Discourse. In A. Kamio, ed., Directions in Formal Linguistics. 117-143. Philadelphia: John Benjamins.

Roberts, Craige. 1996. Information structure in discourse: Towards an integrated formal theory of pragmatics. In J.H. Yoon and A. Kathol, eds., OSU Working Papers in Linguistics 49: Papers in Semantics. 91-136.

Sturgeon, Anne. 2003. Two-tiered approach to binding domain formation: Evidence from Czech. In W. Browne, J.-Y. Kim, B. Partee and R. A. Roth stein, eds., Proceedings from the Annual Workshop on Formal Approaches to Slavic Linguistics. 495-514. Ann Arbor, MI: Michigan Slavic Publications.

Sturgeon, Anne. 2005. Contrastive Left Dislocation in Czech: Evidence for a movement account. Presented at Linguistic Society of America, Oakland, Ca. Meeting.

Van Riemsdijk, Henk and Frans Zwarts. 1997. Left Dislocation in Dutch and the status of copying rules. In E. Anagnostopoulou, H. van Riemsdijk and F. Zwarts, eds., Materials on Left Dislocation. 13-29. Philadelphia: John Benjamins Publishing.

Vat, Jan. 1997. Left dislocation, connectedness and reconstruction. In E. Anagnostopoulou, H. van Riemsdijk, F. Zwarts, eds., Materials on Left Dislocation. 67-92. Amsterdam: John Benjamins.

Anne Sturgeon

Dept. of Linguistics

University of California, Santa Cruz

1156 High St.

Santa Cruz, CA 95064

annemar@ucsc.edu 